\title{
Legal Review of the Publication of Song Covers to Youtube without the Creator's Permission is Reviewed from Law No. 28 of 2014 on Copyright
}

\author{
Siti Nurhayati ${ }^{1}$, Dina Andiza ${ }^{2}$ \\ ${ }^{1,2}$ Law Study Program, Social Science Faculty, Universitas Pembangunan Panca Budi, Medan, Indonesia 20122 \\ Corresponding Author: Siti Nurhayati
}

DOI: https://doi.org/10.52403/ijrr.20220307

\begin{abstract}
Copyright in the field of music and songs has been supported by technological advances one of which is Youtube, with this technological advancement many things can be done by irresponsible people so that it can harm others such as making a cover version of other people's songs and uploading them to Youtube media without getting permission from copyright holders and not infrequently today many become famous and benefit more than creating songs. The collection and collection of data in this study was carried out by document study (Library Research) using skunder data that includes primary, skunder and tertiary legal materials. The results of the study stated that Copyright is an exclusive right where the song cover actor wants to cover the song and seek economic benefits, must get permission / license from the creator so as not to violate the Copyright. Even without recording, copyrighted works have received protection from the Copyright Act. But a copyrighted work would be better if it does the pencant. To cover the song must also be in accordance with certain conditions so as not to violate copyright, and uploading the video cover of the song on Youtube without the creator's permission is a form of law against copyright. Copyright infringement is caused by a factor that causes a lack of awareness of copyright infringement, cultural factors and one of them is economic factors, so many parties who make song covers without the creator's permission and upload to Youtube media benefit from the upload.
\end{abstract}

Keywords: Cover Publication, Youtube, Copyright

\section{INTRODUCTION}

Intellectual Property Rights is a tool to achieve and develop the economy, in the narrow sense of the creator or inventor itself, and in the broadest sense for the improvement of the country's economy as one of the sources of foreign exchange. For example, one of them that has the potential to be developed in the current era of the creative economy is artwork Therefore, it takes things that can guarantee and protect the rights of the creator of each work in the form of legal protection given to the creator. (Sophar Maru Hutagalung, 2017) Judging from the development of Intellectual Property Rights was first translated into "Intellectual Property Rights" then became "Intellectual Property Rights". The common term used now is Intellectual Property Rights abbreviated as IPR. (Abi Jam'an Kurnia, 2021)

Basically, the concept of Intellectual Property Rights is a form of appreciation of the results of human creativity, both in the form of inventions and works of copyright and art (art and literary work). (Kholis Roisah, 2015). IPR is categorized as Intellectual Property Rights considering that IPR ultimately produces intellectual works in the form of knowledge, art, literature, technology, which in realizing it requires 
the sacrifice of energy, cost time, and thought.

The protection of intellectual property rights is held for the purpose of giving an award to someone who has poured his ideas and ideas into a work. The abbreviation for Intellectual Property Rights is no longer used and turned into Intellectual Property. Regarding the change of this term can be known through Article 25 of The Seventh Section of Presidential Regulation of the Republic of Indonesia Number 44 of 2015 concerning the Ministry of Law and Human Rights in the article used istirlah "Directorate General of Intellectual Property" not "Directorate General of Intellectual Property Rights".(Ni Ketut Supasti Dharmawan, 2016)

One of the intellectual works that goes into intellectual property is copyright. (Bernad Nainggolan, 2016) Copyright is one of the branches of Intellectual Property Rights in general that has been recognized both internationally and nationally. This is evidenced by the emergence and enactment of international kovensis and other regulations governing copyright Some of these rules can be seen on an international scale the emergence of TRIPs (Agreement on Trade Related Aspects of Intellectual Property Rights) in which also touch on the issue of Copyright.(Arif Lutyiansori, 2019)

Basically, Copyright is an appreciation for the creativity of the creator, so that it can regulate the use of the results of the pouring of ideas or information, and the right to announce or multiply his creation, or give permission for it. Therefore, every copyright work that is registered and gets protection must be respected and appreciated. (Tim Visa Yustisia, 2015). Copyright does not require the creation to be registered, but if registration is done then this will be better, because with registration there will be formal proof of copyright ownership.(Tim Visa Yustisia, 2017) The Law calls copyright the exclusive right for the creator or recipient of the right to announce or reproduce his or her creation or give permission for it without prejudice to restrictions according to applicable laws and regulations.(Tim Visa Yustisia, 2017)

When viewed in Law No. 28 of 2014 on Copyright Article 40 paragraph (1) letter $\mathrm{d}$ mentioned that the song and all song copyright works are protected creations. One of the objects of copyright is the song. A song is a musical unity consisting of a sequence of various tones. (Otto Hasibuan, 2018). Cover version or cover is the result of reproduction or rendition of a song that has previously been recorded and performed by other singers / artists. Not a few, a cover version song even becomes more famous than the song performed by the original singer. (Lucky Setiawati, 2021) Changing other people's songs for commercial purposes without permission and uploading video covers of songs through Youtube is what causes many violations of copyright that occur on the Youtube site.

Currently, there are many who make cover versions of songs belonging to others and upload them to Youtube media. The problem that often occurs today is that people who broadcast or upload cover version videos do not get permission from copyright holders and it is not uncommon nowadays many become famous and benefit more than who create songs.

Examples such as the case of Shady Umbrella Band whose song was covered or re-sung by artist Hanin Dhiya entitled "Akad" which was uploaded to Hanin's Youtube media. Hanin made the cover of the song without asking the songwriter's permission. From these examples it is known that Hanin has earned or benefited from songs belonging to the Shady Umbrella Band.

In terms of legality, Youtube media itself allows cover versions to circulate, as long as the Copyright Holder gives permission (license). However, the lack of awareness of the appreciation of the Indonesian people, some people choose to create and distribute cover versions of someone's copyright illegally so as to violate copyright. Ironically, the view that 
copyright crimes are not too evil not only among the lay community, but also to law enforcement officials. (Lucky Setiawati, 2021)

\section{LITERATURE REVIEW Song Cover Publication}

Publication is the implementation of information dissemination activities. According to the Great Dictionary of Indonesian, the meaning of the word publication is an announcement. Another meaning of publication is that it means publishing. According to Law No. 28 of 2014 on Copyright Article 1 number 11 defined announcement is the reading, broadcasting, exhibition, a creation using any tool either electronic or non-electronic or doing in any way so that a creation can be read, heard or seen by others.

The cover of a song or cover version is the result of reproduction or rendition of a song that has previously been recorded and performed by other singers / artists. When interpreted as a whole the publication of the song cover is an activity of publishing or uploading video covers of songs through internet media such as Youtube, Instagram, and other media.

\section{Media Youtube}

Youtube is an internet-based digital platform that presents various conveniences to the public to enjoy video content for free. Not only being a video lover but this site allows users to upload and share videos practically. Understanding the internet at least requires a conceptual leap, because the internet is not just a network, but a network of various networks. (Yusran Usnaini, 2019) The number of artists / singers to ordinary people has enjoyed the benefits of the internet one of which is Youtube.

YouTube was founded on February 14, 2005 and is a subsidiary of Google Inc. (Jesica Laurencia, 2021) The rampant use of Youtube to upload videos for commercial or non-commercial purposes turns out to open the opportunity for copyright infringement.

\section{The Creator's Permission}

The Creator is a person or a person who individually or together produces a creation that is distinctive and personal. The term songwriter is sometimes pronounced as composer meaning someone who produces song creation, distinguished from the poet who makes poetry.

\section{Copyright}

Copyright is a special right owned by the creator to produce his work or give permission to others to do so but within the limits of applicable law. (Endang Purwaningsih, 2015) While creation is any work created in the fields of science, art, and literature produced by inspiration, ability, mind, imagination, dexterity, skill, or expertise expressed in real form. The Law provides the understanding that copyright is an exclusive right for creators and copyright holders to announce or reproduce their creation, which arises automatically after a creation is born without prejudice to restrictions according to applicable laws and regulations. Khoirul Hidayah, 2017)

\section{METHODOLOGY}

This study uses descriptive research. Descriptive research aims to precisely describe the traits of an individual, circumstance, symptom or group or to determine the spread of a symptom or to determine the relationship between one symptom and another in society. (Amiruddin dan H. Zainal Asikin, 2017)

This type of research is Normative Law. Normative Law Research is research that refers to legal norms contained in laws and regulations. (Soerjono Soekanto dan Sri Mamudji, 2019) This library research examines the study of documents, namely using various data such as laws and regulations, court decisions, legal theories, and can be in the opinion of scholars.

The technique of data collection in this research is to use the Library Research method. Literature technique is "Literature research that is carried out by reading, 
studying and recording various literature or reading materials that are in accordance with the subject matter, then filtered and poured in the framework of theoretical thinking". (Kartini Katono, 2018)

The study used secondary data. Secondary data reviewed from its binding power according to Ronny Hanitijo Soemitro is distinguished into Primary Law material, Secondary Law material, Tertiary Law material. (Bambang Sunggono, 2017)

Qualitative Research Method is a research method based on philosophy, which is used to examine scientific conditions (experiments) where researchers as instruments, data collection techniques and analyzed that are qualitative are more pressing on the meaning of. (Sugiyono, 2018) Qualitative analysis of this data is sourced from legal material based on concepts, theories, and laws and regulations regarding the publication of song covers to Youtube media without the permission of the Copyright Holder.

\section{RESULTS AND DISCUSSION}

\section{Legal Protection Against Copyright} Holders Whose Song Creations Are Published as Song Covers on Youtube Media

The use of internet technology today brings profits and also brings losses in the music industry, especially some copyright violations in the form of song announcements and doubling of songs / music without the permission of the creator. Currently, there are many parties who make song covers or re-perform songs without the creator's permission and without paying royalties uploading them to Youtube media. In the Copyright Act does not know about the cover of songs, which is known is the term doubling.

In Law No. 28 of 2014 on Copyright is known as the principle of automatical protection, which means a copyright work that is realized or created by its creator, then since then automatically the copyright has copyright and gets legal protection. Copyright in Article 4 is an exclusive right consisting of moral rights and economic rights. Moral rights are the eternally inherent right of the creator, while economic right is the creator's exclusive right to economic benefit over creation.

Legal protection is an act to protect a person's right to justice based on the law that is in force preventively and reflexively.(Abiantoro Prakoso, 2016) According to Satjipto Rhardjo, Legal protection is an effort to protect a person's interests by allocating a power to him to act in the framework of his interests.(Satjipto Rahardjo, 2018) Copyright infringement in the field of song / music in the form of covers can be done through two means of protective measures, namely preventive protection measures and repressive protection measures.

Preventive protection includes preventive measures to prevent the occurrence of sangketa while repressive protection is more protection to efforts to resolve disputes.(Budi Agus Riswandi dan Shabhi Mahmashani, 2019) Protection of works of creation has been automatically protected, but other things such as the idea of ideas do not get copyright protection because copyright works are real and born based on creativity / ability so that creation can be heard, read, seen.( Adrian Sutedi, 2018)

The basic concept of copyright protection is that copyright protected is an idea that is tangible and original, the existence of tangible forms and something tangible is the original is not the result of plagiarism. This is one of the conditions that must be met in order to protect copyright. Songs sung by someone spontaneously are not recorded, it cannot be copyright protection. However, if the song is sung, recorded tangible and original proved not to be a plagiarized, it only gets copyright protection.

Creation appears do not need to be recorded to promote a copyright protection, only with the emergence of an idea of creation it is considered to exist. Announced 
or unannounced creations are already under Copyright protection.

Copyright Registration is very important for the creator because it facilitates proof in the event of a dispute regarding Copyright. Copyright is an exclusive right where the cover actor must obtain permission or license in writing so as not to violate the Copyright. Even without recording, the song's copyright work has received protection from Law No. 28 of 2014 on Copyright. But a copyrighted work will be better if you register.

According to Law No. 28 of 2014 on Copyright Article 1 paragraph (2) states that "the Creator is one or several persons who individually or together produce a creation that is distinctive and personal", While what is meant by Creation according to Law No. 28 of 2014 on Copyright Article 1 paragraph (3) states that "Creation is every work created in the fields of science, art, and literature produced by inspiration, ability, mind, imagination, dexterity, skill, or expertise expressed in real form".

A songwriter can license the song to another party. By licensing the song to another party, the songwriter is required to earn royalties.(Risa Amrikasari, 2021) In the Copyright Act, this license is regulated in Articles 80 to Article 83. Unless otherwise promised, the Creator reserves the right to grant licenses to other parties under a written agreement for a period of time. Determinations for obtaining royalties and granting procedures are made based on a licensing agreement between the creator and the licensee.

The cover of the song that was created and uploaded to Youtube media, the inclusion of the original singer's name on the cover work is certainly not enough to avoid lawsuits by copyright holders. In order not to infringe copyright, to produce, record, and or announce a song belonging to the creator, the party must obtain permission (license) from the creator as follows:

1. License to Mechanical Rights, i.e. the right to duplicate, reproduce (including re-arranging) and record a music/song composition on $\mathrm{CD}$, cassette tapes and other recording media; and or

2. Performing rights, which is the right to announce a song / musical composition, including singing, playing, either in the form of recording or performing live, via radio or television.

Copyright protection is essential to human creativity, where the creator is granted recognition (Moral Rights) and awards (Economic Rights). Thus the creation and dissemination of art and literature became developed. As stipulated in Law No. 28 of 2014 on Copyright, states that an Announcement is a reading, broadcasting, exhibition, a creation using any tool whether electronic or nonelectronic or doing in any way so that a creation can be read, heard, and seen by others.

In the above article that copyright protection includes electronic media (internet). The concept that discusses the protection of law contained in Law No. 28 of 2014 on Copyright, namely in Article 40 paragraphs 1 to 3 which mentions that about protected creation. The Copyright Act of 2014 states that the license agreement is valid for a period of time and does not exceed the validity period of Copyright and Related Rights. Unless otherwise promised, the implementation of the license is accompanied by the obligation of the licensee to grant royalties to the Copyright holder or the owner of related rights during the license term.

Determination of the amount of royalties and procedures for granting royalties, is done based on a license agreement between the copyright holder or the owner of the related rights and the licensee. The amount of royalties in the license agreement must be determined based on the prevalence of applicable practices and meets the element of fairness. With the license agreement in writing the video cover of the song does not violate copyright.

The amount of royalties received by the loyal power of attorney depends on: 1. whether the song has been registered. 
2. whether the song is actually played.

3. how much real royalty income YKCI earned that year for the category of users who played the song.

4. How often the song is played.(OK Saidin, 2015)

In the protection of the Law for Copyright there are several obstacles faced in the balance of regulations on legal protection in Copyright, namely:

1. The public's view of Copyright to this day is different from Law No. 28 of 2014 on Copyright. Some people still see copyright as a joint property while in Law No. 28 of 2014 on Copyright see copyright as private property. This difference is one of the causes of rampant copyright infringement in the community. (Gatot Supramono, 2017) The difference is also due to the copyright law, each less public. (Gatot Supramono, 2017) People still do not understand what copyright is and the public may not be aware of the laws governing it.

2. Lack of knowledge or lack of information that the songwriter has on matters relating to copyright registration. If the songwriter registers the Copyright the creator of the song can protect copyright, the songwriter and the public do not pay attention that the importance of registering a copyright.

3. Actors who do the cover of the song or who re-sing the song do not understand about the exclusive rights owned by copyright holders, namely moral rights and economic rights. The perpetrator who did the cover of the song considers that to ask permission to the Copyright holder is not so important, by including the name of the creator and the title including not infringing copyright.

4. Lack of legal action for the perpetrators of song covers that violate copyright, if it continues to happen will give rise to the attitude that to sing someone else's song or cover the song is common and not unlawful.
5. In addition to the lack of legal action, the obstacles faced are caused by advances in technology and information that facilitate copyright infringement. With the development of technology and information will cause more cover actors if they do not develop legal action for cover actors.

Of the few obstacles faced in copyright protection is the low or lack of public awareness of copyright because most are not familiar with copyright law.

\section{Due to the Law of The Act of Publishing Song Covers on Youtube Media Without The Permission of Copyright Holders}

a. Factors Causing The Occurrence of Song Cover Publication on Youtube Media Without Permission of Copyright Holders

In the current era of globalization has developed various communication tools and internet media technology is often used to carry out various activities. Copyright infringement of songs that often occur is doubling, multiplying songs by plowing without the permission of the creator. (Otto Hasibuan, 2018) Copyright infringement is often termed as piracy. In this case quite a lot occurs due to lack of awareness of the causes of copyright violations in Indonesia not paying attention to the rule of law.

Currently the creative industry is much in demand in the digital era through various platforms such as Youtube, with the development of technology everyone is free to upload various content including performing cover songs belonging to other singers.

However, often it is poorly understood about copyright. Whereas the rules on Copyright have been applied in Law No. 28 of 2014 on Copyright Article 1 paragraphs 1 to 4 contains about the definition of Copyright, Creator, Creation, and Copyright Holder.

This is the next background why there are many causes of copyright infringement in Indonesia. Everyone commits a violation in essence inseparable 
from such deviant behavior. This deviant behavior is caused by several influencing factors. According to Kinberg, the relationship between these factors is:

1. Dynamic factor, this factor actively encourages a person to perform certain actions such as the urge to acquire something. In this factor, there is a goal that the perpetrator wants to achieve.

2. Static factor, which is a factor that can passively make it easier for a person to perform certain actions. It was due to a lack of power to resist the impulse of his intention desires.

From some of the above factors clearly that a person commits a violation is essentially inseparable from both factors, both dynamic factors (from the outside) and static factors (from the inside).

In the dynamic factors there are aspects that encourage someone to commit copyright infringement, namely:

1. Dynamic Factors
a. Cultural Aspects
b. Economic Aspects
c. Juridical Aspects
d. Sociological Aspects

2. Static Factor

\section{Religious Aspects}

Parties who plagiarized, hijacked and who re-sang songs (cover songs) without the permission of the Copyright holder, often do not realize the error. Many even mentioned that they were the ones who helped the song become popular. Examples such as the case of Hanin Dhiya who re-sing (cover) a song called Akad sung by the Shady Umbrella Band. Hanin sang the song and became famous without permission to the creator and singer of the Shady Umbrella Band which is none other than Mohammad Istiqamah Djamad (Is). The scope of Copyright, which is when the creator announces his work to the public. In addition, the scope is also when the creator increases the copyright work of the song. (Hukamnas, 2021)

There are several factors that cause violations of copyright, so copyright infringement is generally influenced by the following factors:

1. Seeking Profit, The Party who commits a person's Copyright infringement because he wants to obtain something large enough profit, without paying royalties for the creator and / or copyright holder (licensee) or payment of taxes for the State.

2. Low Public Legal Awareness, the cause of copyright infringement in Indonesia is the lack of awareness. Piracy like this often afflicts musicians or creators, can be seen clearly with many of them who enter into copyright infringement by making song covers and uploaded to internet media such as Youtube without the permission of copyright holders for reasons for the sake of seeking profits and high economic value.

3. Cultural Factors, violations of copyright because the act is considered something reasonable and mediocre in the citizens of the community, and realized or not repeatedly often done without some kind of warning and threat to violators, such as doubling the creation of others, whether doubling the books, CDs / DVDs, songs / music and others belonging to others commercialized.

4. Technological Progress Factor, technological developments like today are increasingly growing rapidly. This technology is very influential in terms of copyright crimes where the process of harm is all influenced by technological advances. Because that's why many copyright violators against song covers or re-singing songs on internet media one of them youtube.

Some of the above factors that cause copyright easing occur. There are still many song cover actors who do publish to Youtube media without the creator's permission and get economic benefits. This is very detrimental for the copyright holder as the owner of the song. To avoid copyright infringement on Youtube, YouTube asks creators to understand the rules of Youtube. Whether for copyright 
owners or those who create content, complying with Youtube rules can help in preventing violations and make Youtube a positive medium.

\section{b. The Act of Publishing Song Covers on Youtube Media as An Unlawful Act}

Advances in the information technology sector that bring about changes in communication processes, the role of telecommunications is increasingly important as a result of the demands of the activities of the modern world that is fastpaced and global. (OK Saidin, 2015) The use of information, media, and communication technologies is changing people's behavior globally. The rise of internet media has brought about rapid social, economic, and cultural changes. Various innovations and conveniences that arise through internet media are also a place of crime and copyright infringement. With this, many forms of creation are realized into digital form and then spread to the internet media, one of which is Youtube.

This problem is an unlawful act that uses advanced technological means of copyright infringement in the internet media that is difficult to trace, which makes proving it difficult compared to ordinary unlawful acts. (Ahmad M. Ramli, 2016) Copyright infringement activities are influenced by various factors. The level of public understanding of the meaning and function of copyright, attitudes and desires to profit easily, and the actions of law enforcement in the face of copyright infringement, are factors that gain attention. (Eddy Damian, 2019)

Speaking of violations as above, this means contenting with violations of the moral rights and economic rights of the creator. Acts that include violating the moral rights of the songwriter:

1. Negate or not mention the name of the songwriter when it is published.

2. Put his name as the creator of the song.

3. Change or change the title of the song.

4. Change the content of the song. (Otto Hasibuan, 2018)
And the following actions that are classified as violations of the economic rights of songwriters include:

1. Acts without permission announce the creation of the song:

a. Singing and singing songs in public;

b. Listen to songs to the public (play recordings of songs intended for the public);

c. Broadcasting songs to the public (such as radio and television);

d. Distribute songs to the public (distribute songs that have been recorded on CD / DVD or published to the internet media);

e. Spreading the song to the public (the same as distributing);

f. Selling songs (which is the same as distributing but emphasized to profit from others).

2. Acts without permission to multiply the creation of the song:

a. Recording the song;

b. Duplicate or produce songs mechanically or in writing;

c. Adapting or re-interpreting the song;

d. Arranging the song;

e. Translate songs (Otto Hasibuan, 2018)

The intent directly and indirectly harms the copyright holder given the economic rights that should be accepted and granted to the creator. Because many parties easily enjoy the results without spending money. One of them re-sings the song or cover version. Cover version or cover is the result of production or rendition of a song that has previously been recorded and performed by other singers / artists. (Lucky Setiawati, 2021) According to Law No. 28 of 2014 on Copyright Article 44 paragraph 1 states that "The use, retrieval, multiplication, and/or alteration of a Creation and/or related rights product in whole or in part substantially is not considered a violation of copyright if the source is mentioned or listed in full for the purposes".

Violations on youtube sites often occur because the new Youtube party will 
follow up that violates copyright when there is a notice of copyright infringement. Youtube itself has provided a system called Content ID. The function of Content ID is to protect the video and give full copyright to you as the owner of the original video. The goal is that others cannot confess or reuse or reproduce the content of the video, with special conditions. (Gani Sebastian, 2021) Through this content ID will analyze each video uploaded determines whether the video contains Copyright viewed from the audio, composition, and video.

So many factors that make the economy of songwriters, singers and musicians not good in Indonesia, the fact that is often complained about is the lack of public appreciation for copyright and the lack of protection of copyright law, especially the legal protection of the economic rights of creators and related parties. (Otto Hasibuan, 2018)

\section{c. Due to the Law of The Act of Publishing Song Covers on Youtube Media Without The Permission of The Copyright Holder.}

The phenomenon of violations of copyright, especially in the form of announcements of songs and / or music today as if many are taking place without any meaningful legal settlement. An act can be said to be a violation of copyright if it violates the special rights of the creator or copyright holder. (Adrian Sutedi, 2018) Utilizing information, media and communication technologies has changed people's behavior globally. The emergence of internet media in people's lives has undergone changes in the social, economic, cultural fields that are taking place very quickly.

Uploading a video of the song cover on Youtube media without the copyright holder's permission is a violation of the creator's economic rights. Currently any party can upload a video cover of the song even though it turns out to be a form of copyright infringement, and this of course harms the creator. Copyright infringement is influenced by several factors. The low level of public understanding of the meaning and function of copyright, attitude and desire to obtain trade profits in an easy way, coupled with not enough improvement in the common understanding, attitude, and actions of law enforcement officials in the face of copyright violations, is a factor that needs attention.(Eddy Damian, 2019)

Youtube media as a provider of information in the form of videos must be able to act decisively in making rules in uploads so that no one else violates copyright. As outlined above, that there are legal consequences for copyright infringement in utilizing the economic rights of the copyrighted music/ song without the permission of the legitimate creator. Against any copyright infringement in the form of no permission from the creator, in Law No. 28 of 2014 on Copyright there are legal consequences / sanctions for those who commit violations. Law No. 28 of 2014 on Copyright has provided protection to creators civilly and criminally in accordance with Article 113 mentioning that:

1. Any Person without the right to commit a violation of economic rights as referred to in Article 9 paragraph (1) letter $\mathrm{i}$ for Commercial Use is punished with a maximum imprisonment of 1 (one) year and/or a maximum fine of $\mathrm{Rp}$ $100,000,000$ (one hundred million rupiah).

2. Any Person without the rights and/or without the permission of the Creator or copyright holder committing a violation of the Creator's economic rights as referred to in Article 9 paragraph (1) letter c, letter d, letter $\mathrm{f}$, and/or letter $\mathrm{h}$ for Commercial Use is punishable by imprisonment of a maximum of 3 (three) years and/or a maximum fine of Rp500,000,000, 00 (five hundred million rupiah).

3. Any Person without the rights and/or without the permission of the Creator or copyright holder committing a violation of the Creator's economic rights as 
referred to in Article 9 paragraph (1) letter $a$, letter $b$, letter e, and/or letter $g$ for Commercial Use is punishable by imprisonment of a maximum of 4 (four) years and/ or a maximum fine of Rp1,000,000,000, 00 (one billion rupiah).

4. Any Person who fulfills the elements referred to in paragraph (3) committed in the form of piracy, is punishable by imprisonment of a maximum of 10 (ten) years and/or a maximum fine of Rp4,000,000,000.00 (four billion rupiah).

Uploading a video of the song without the creator's permission and broadcast through Youtube, the Youtube site can result in the Youtube site being closed in its entirety. This is in accordance with Law No. 28 of 2014 on Copyright Article 54 and Article 55. Under Article 54 to prevent infringement of Copyright and Related Rights through information technology-based means, the Government is authorized to:

1. Supervision of the creation and dissemination of content in violation of Copyright and Related Rights;

2. Cooperation and coordination with various parties, both domestically and abroad in the prevention of the creation and dissemination of content in violation of Copyright and Related Rights;

3. Supervision of recording by using any media against Creation and Related Rights products at the performance venue.

And under Article 55 states that any person who is aware of copyright and/or related rights violations through an electronic system for commercial use can report to the minister. The minister verified the report as referred to above. What is meant by commercial use is in the medium of information and communication technology includes the direct commercial use (paid) as well as the provision of free content services that benefit economically from those who benefit from the use of Copyright and/or Related Rights.
If you have found evidence that the video contains copyright infringement, the minister who organizes government affairs in the field of communication and informatics can close the content and access of users who violate copyright to make the internet media system service or Youtube inaccessible In essence Youtube policy is not to misuse content belonging to others into original content with commercial purposes. Because in the Youtube system there is called Content ID.

Content ID is a software system created by Youtube to help content owners find copies of their work on Youtube. With the Content ID feature, the copyright owner can choose various actions against copies of his work, namely:

1. Block the entire video so it can't be viewed again (takedown)

2. Track statistics in video views.

3. Monetize the video by running ads on the video.

That way it can cause a deterrent effect to those who create content without the permission of the creator or copyright holder.

\section{CONCLUSION}

Legal protection of Copyright holders whose song creations are covered and published on Youtube media is intended to have the rights of copyright holders or songwriters protected. In Law No. 28 of 2014 on Copyright in Article 4 is the exclusive right of the creator consisting of moral rights and economic rights. Moral rights are the rights that are eternally attached to the creator, while economic rights are the exclusive right of the creator to gain economic benefits over Creation. Other parties can exploit the creator's copyrighted work including song copyright works with permission in the form of a license agreement in writing. Even without recording, copyrighted works have been protected. But a copyrighted work will be better if you do the recording.

Due to the legal act of publishing song covers on Youtube media without the 
permission of copyright holders is currently widely occurring in the world of music and songs. In uploading a video cover of the song on Youtube without the creator's permission it is a form of violation of copyright law. The existence of copyright infringement is caused by a lack of awareness of copyright infringement, cultural factors and one of them economic factors. Many parties who make song covers without the creator's permission and upload to Youtube media can benefit from the upload. As a result of the law if the party commits a violation of copyright there is Article 113 paragraph (3) of Law No. 28 of 2014 on Copyright Any Person without the right of the creator's permission commits a violation of the creator's economic rights as intended in Article 9 paragraph (1) for commercial use is punishable by imprisonment of a maximum of 3 (three) years and a maximum fine of Rp1,000,000,000.00 (one billion rupiah). In Youtube also, if the party uploads the cover of the song on Youtube without the creator's permission it causes the Youtube site to be closed in its entirety. This is in accordance with Law No. 28 of 2014 on Copyright Article 54 and Article 55.

\section{Acknowledgement: None}

\section{Conflict of Interest: None}

\section{Source of Funding: None}

\section{REFERENCES}

1. Amiruddin dan H. Zainal Asikin, 2017, Introduction to Legal Research Methods, Rajawali Press, Jakarta.

2. Damian, Eddy, 2019, Copyright Law, PT. Alumni, Bandung.

3. Dharmawan, Ni Ketut Supasti,2016, Intellectual Property Rights, Deepublish, Yogyakarta.

4. Hasibuan, Otto, 2018, Copyright in Indonesia, Special Review of Song Copyright, PT. Alumni, Bandung.

5. Hidayah, Khoirul, 2017, Intellectual Property Rights Law in Indonesia, UINMaliki Press, Malang.
6. Hutagalung, Sophar Maru, 2017, Copyright Position and Its Role in Development, Sinar Grafika, Jakarta Timur.

7. Katono, Kartini, 2018, Introduction to Methodological Research, ALUMNI, Bandung.

8. Lutyiansori, Arif, 2019, Folklor Copyright and Protection in Indonesia, FH UII, Yogyakarta.

9. Nainggolan, Bernad, 2016, Empowerment of Copyright Law and Collective Management Institutions, PT. Alumni, Bandung.

10. Rahardjo, Satjipto, 2018, The Other Side of the Law in Indonesia, Kompas, Jakarta.

11. Ramli, Ahmad, 2016, Cyber Law and HAKI in the Indonesian Legal System, PT. Refika Aditama, Bandung.

12. Riswandi, Budi Agus dan Shabhi Mahmashani, 2019, Intellectual Property Rights Dynamics of Creative Societies, Pusat HKI FH Universitas Islam Indonesia, Yogyakarta.

13. Roisah, Kholis, 2015, The Legal Concept of Intellectual Property Rightsl, Setara Press, Malang

14. Soekanto, Soerjono dan Sri Mamudji, 2019, Normative Legal Research :A Brief Review, Raja Grafindo, Jakarta.

15. Sutedi, Adrian, 2018, Intellectual Property Rights, Sinar Grafika, Jakarta.

16. Sunggono, Bambang, Legal Research Methods, Cet 5, PT. Raja Grafindo Persada, 2017, Jakarta.

17. Sugiyono, Quantitative, Qualitative, and R\&D Research Methods, Alfabeta, 2018, Bandung.

18. Usnaini, Yusran, 2019, Copyright and Its Challenges in the Age of Cyber Space, Ghalia Indonseia, Bogor.

19. Yustisia, Tim Visa, 2015, Official Copyright Guide from Registering, Protecting, to Resolve, Sangketa, Visi Media, Jakarta Selatan.

20. Kitab Undang-Undang Hukum Perdata Undang-Undang Republik Indonesia Nomor 28 Tahun 2014 Tentang Copyright

21. Dewi, Mirah Satria, 2017, "Copyright Law Protection Against Song Cover Versions on Youtube", Vol. 6, No. 4, Jurnal Magister Hukum Udayana, Fakultas Hukum, Universitas Udayana, Bali.

22. Setiawati, Lucky, Copyright in the Music Industry, https://www.hukumonline.com/klinik/detail/ 
Siti Nurhayati et.al. Legal review of the publication of song covers to Youtube without the creator's permission is reviewed from law no. 28 of 2014 on copyright.

ulasan/lt506ec90e47d25/apakah-

menyanyikan-ulang-lagu-orang-lain-

melanggar-hak-cipta/, Accessed

November $22^{\text {th }} 2021$.

23. Laurencia, Jesica. Kompas, Get to know YouTube,

https://www.kompasiana.com/jesicalaurensi a/56cb0156c0afbd3218bb231e/mengenalyoutube/, Accessed on November $1^{\text {st }} 2021$

24. Kurnia, Abi Jam'an, Legal Basis changes the term HAKI to IPR, then KI, https://www.hukumonline.com/klinik/detail/ ulasan/cl3290/dasar-hukum perubahanistilah-haki-menjadi-hki--kemudian-ki/, Accessed on November $17^{\text {th }} 2021$

25. Kamus Besar Bahasa Indonesia (KBBI), https://kbbi.web.id/publikasi, Accessed on October $24^{\text {th }} 2021$.

26. Hukumnas, Causes of Copyright Infringement in Indonesia, https://www.google.co.id/amp/s/hukamnas.c om/penyebab-terjadinya-pelanggaran-hak- cipta/amp/ Accessed on November $13^{\text {th }}$ 2021

27. Amrikasari, Risa, The Law Snares If Singing Someone Else's Song Without Permission, https://m.hukumonline.com/klinik/detail/ula san/lt54b9fc67d1bcd/jerat-hukum-jikamenyanyikan-lagu-orang-lain-tanpa-izin/ Accessed on November $10^{\text {th }} 2021$

28. Sebastian, Gani, How to Get and Use Youtube Content ID, https://www.klikmania.net/menggunakancontent-id-youtube/ Accessed on November $14^{\text {th }} 2021$.

How to cite this article: Siti Nurhayati, Dina Andiza. Legal review of the publication of song covers to Youtube without the creator's permission is reviewed from law no. 28 of 2014 on copyright. International Journal of Research and Review. 2022; 9(3): 48-59. DOI: https://doi.org/10.52403/ijrr.20220307 